\title{
Quantifying the Cost of Substandard Patents: SOME Preliminary EVIDENCE
}

\author{
T. Randolph Beard* \\ George S. Ford, Ph.D.** \\ Thomas M. Koutsky ${ }^{*}$ \\ Lawrence J. Spiwak $^{* * *}$
}

12 YALE J.L. \& TECH. 240 (2010)

\begin{abstract}
The purpose of patent policy is to balance the incentive to invent against the ability of the economy to utilize and incorporate new inventions and innovations. Substandard patents that upset this balance impose deadweight losses and other costs on the economy. In this paper, we examine some of the deadweight losses that result from granting substandard patents in the United States. Under plausible assumptions, we find that the economic losses resulting from the grant of substandard patents can reach $\$ 21$ billion per year by deterring valid research with an additional deadweight loss from litigation and administrative costs of $\$ 4.5$ billion annually. This brings the total deadweight loss created by our "dented" patent system to be at least $\$ 25.5$ billion annually. These estimates may be viewed as conservative because they do not take into account other economic costs from our existing patent system, such as the consumer welfare losses from granting monopoly rents to patent holders that have not, in the end, invented a novel product, or the full social value of the innovations lost.
\end{abstract}

\footnotetext{
${ }^{*}$ Senior Fellow, Phoenix Center for Advanced Legal \& Economic Public Policy Studies; Professor of Economics, Auburn University, Auburn, Alabama.

${ }^{* *}$ Chief Economist, Phoenix Center for Advanced Legal \& Economic Public Policy Studies.

${ }^{* * *}$ Resident Scholar, Phoenix Center for Advanced Legal \& Economic Public Policy Studies.

${ }^{* * * *}$ President, Phoenix Center for Advanced Legal \& Economic Public Policy Studies. The views expressed in this paper are the authors' alone and do not represent the views of the Phoenix Center, its Adjunct Fellows, or any of its individual Editorial Advisory Board members.
} 


\section{TABLE OF CONTENTS}

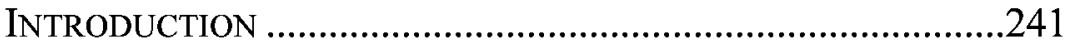

I. Sources and Costs of A "LoOSE" Patent System ..............243

II. The Equilibrium Level of Valid and Substandard

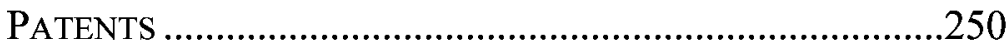

III. QUANTIFYING THE COSTS OF SUBSTANDARD PATENTS ...........255

A. Lost Patents................................................................ 257

B. Other Deadweight Losses ............................................ 264

C. Review of the Evidence ................................................ 268

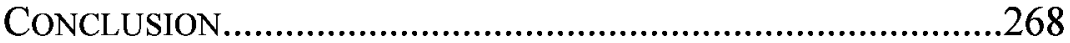

\section{INTRODUCTION}

Patent policy necessarily involves a balance between encouraging inventors to create new products while simultaneously ensuring that innovations become diffused throughout the economy. Protecting intellectual property is a lynchpin of a vibrant, modern economy, and while the benefits of the patent system are undeniable, the system also imposes significant cost on the economy-even in the best of circumstances. Several highprofile patent disputes, such as the Blackberry ${ }^{1}$ and Microsoft $\mathrm{MP}^{2}$ cases, have sparked a debate as to whether the U.S. patent law system adequately promotes the interests of inventors or whether the system is a legal quagmire that stalls new innovation in excessive litigation. ${ }^{3}$ When a patent system grants substandard patents or provides overly permissive legal remedies for patent holders, the protection of intellectual property can create substantial net loss of economic welfare. We envision a "substandard patent" as one that is not privately profitable to pursue in the absence of litigation opportunities afforded through inevitable imperfections in the legal system. Although such a patent does not protect an invention worth protecting from the social point of view, they may be privately profitable because the sometimes afford the opportunity to obtain payments from holders

1 The dispute between patent holder NTP Inc. and BlackBerry smartphone manufacturer Research in Motion Ltd. resulted in a settlement of $\$ 612.5$ million. See Important Dates in BlackBerry Patent Case, http://www.msnbc.msn.com/id/ 11409695 (last visited Apr. 15, 2010) (providing a detailed timeline of the case).

${ }^{2}$ Saul Hansell, MP3 Patents in Upheaval After Verdict, N.Y. TIMES, Feb. 23, 2007, http://www.nytimes.com/2007/02/23/technology/23patent.html.

${ }^{3}$ For a summary of the ills of the modern patent system and critiques against it, see ADAM JAFFE \& JOSH LERNER, INNOVATION AND ITS DISCONTENTS: HOW OUR BROKEN PATENT SYSTEM IS ENDANGERING INNOVATION AND PROGRESS, AND WHAT TO DO ABOUT IT (2004). As the National Research Council of the National Academies noted, "patents on trivial innovations may confer market power or allow firms to use legal resources aggressively as a competitive weapon without consumer benefit." NAT'L RESEARCH COUNCIL OF THE NAT'L ACADS., A PATENT SYSTEM FOR THE 21ST CENTURY 95 (2004). 
of sufficiently similar or related "real" patents which are practiced. So, while a well-functioning patent system will necessarily balance the benefits of innovation with the costs of monopoly, a defective system adds to the social costs of patent monopolies the additional deadweight losses arising from reduced innovation and from the wasted resources directed at securing and protecting substandard patents, without providing any offsetting benefit. In economic terms, such substandard patents represent options permitting transfers of wealth from the holders of legitimate patent rights to those holding related, substandard patent claims. Their social value is low (or zero), yet their private option value rises with defects in the patent system.

The economic costs of substandard patents are highlighted by (but by no means limited to) "patent troll" litigation, to which a substandard patent regime can give rise. "Patent troll" litigation is one form of litigation arbitrage-it will exist in areas in which patents are relatively easy to obtain and the consequences to a defendant accused of infringement of losing a patent suit can be enormous and irreversible, such as an injunction against any future sales of a successful yet potentially infringing product. The presence of this arbitrage indicates that the current patent licensing and enforcement system are in need of reform and a thoughtful rebalancing of incentives.

In this Article, we attempt to quantify in a preliminary manner a portion of the cost to the United States' economy of substandard patents granted by the United States Patent and Trademark Office (USPTO). In particular, we focus upon deadweight losses that result from the impact that a "loose" patent system that unduly grants "substandard" patents has upon innovation and the development of important, valid patents. These costs are deadweight losses and not merely transfers, so they reduce overall economic welfare. In the United States, we estimate that the deadweight loss of a "loose" patent system from lost innovation is approximately $\$ 21$ billion each year in private costs alone, or nearly $\$ 200$ per household per year. This sizeable deadweight loss constitutes approximately $7 \%$ of annual Research and Development ("R\&D") spending. Deadweight losses from litigation and administrative costs from substandard patents constitute an additional $\$ 4.5$ billion annually, or $1.5 \%$ of the country's annual R\&D spending.

Our findings are described as preliminary, since there is very limited data upon which to base our estimates. However, we believe that our methods render conservative estimates because we do not take into account a number of other costs created by substandard patents. Most notably, in cases where a substandard patent allows a firm to enforce monopoly prices without truly 
innovating, there is a welfare loss without commensurate benefit that our model does not attempt to quantify. We also ignore the fact that innovation has a greater social benefit than private benefit, so the social costs of lost innovation stand to be much larger than the $\$ 21$ billion in annual private costs from lost innovation that we estimate. $^{4}$

In Part I, we provide a brief description of the general problem of substandard patents and their causes and consequences. Our discussion is succinct, since there are many studies on this issue that are readily available to interested parties. In Part II, we explain an important component of our model, which focuses on the important interactions between the equilibrium level of "valid" and "substandard" patents. We show that substandard patents impose deadweight losses on the economy as a whole because they deter innovation and the development of important, valid patents. This idea serves as the basis for the estimation that we perform in Part III. Part III also contains a sensitivity analysis to allow the inputs to vary over the range of plausible values. Our findings are summarized in the Conclusion.

\section{Sources And Costs of A "Loose" Patent System}

A well-functioning patent system engages in a delicate balance. In order to "promote the progress of Science and useful Arts," a patent holder is granted a legal exclusive monopoly to an invention for a limited period of time. It is thought that granting monopoly profits to patent holders would direct societal resources towards scientific and useful innovations. Thomas Jefferson once wrote that patent law is about "drawing a line between the things which are worth to the public the embarrassment of an exclusive patent and those which are not."6

What Jefferson calls the "embarrassment" of a legal patent monopoly, economists would call a social cost. By definition, the granting of a monopoly reduces output and causes a net loss in consumer welfare. The traditional justification for patent rights is predicated upon the assumption that without such monopoly rights, society will not achieve the optimal rate of innovation because innovations and scientific discoveries are, absent patent rights, often public goods that provide limited or no opportunity for the

\footnotetext{
${ }^{4}$ See, e.g., Charles Jones \& John Williams, Measuring the Social Return to R \& $D$, 113 Q.J. ECON. 1119 (1998); Adam Jaffe, Nat'1 Bureau of Econ. Research, Economic Analysis of Research Spillovers Implications for the Advanced Technology Program (Dec. 1996), http://www.atp.nist.gov/eao/gcr708.htm.

${ }^{5}$ U.S. CONST. art I, § 8, cl. 8.

${ }^{6}$ Bonito Boats, Inc. v. Thunder Craft Boats, Inc., 489 U.S. 141, 148 (1989) (citing 13 WRITINGS OF THOMAS JEFFERSON 335 (Memorial ed. 1904)).
} 
inventor to recover the costs of discovery. If every invention could be immediately copied, then few firms would invest the resources necessary to invent new products. Absent patent rights, an inventor also would have an incentive to prevent others from learning about any new discovery. ${ }^{7}$ A patent attempts to remedy these problems by giving the inventor the legal right to collect some portion of the social value attributable to the invention while inducing disclosure of the details of the invention to the public. ${ }^{8}$ This disclosure, in turn, likely increases innovative activity in that area due to increased information. ${ }^{9}$

At the same time, granting too much protection to inventors (or granting it too easily) can hamper the creation and diffusion of technology throughout the economy. Achieving an adequate balance of rights to compensate true innovators and fostering the use of patented technology is the goal of a well-functioning patent system. A patent regime that makes it too easy to obtain and enforce a patent could create too many of these monopoly "embarrassments" that would reduce economic welfare by virtue of their monopoly status yet not promote economic welfare because they do not reward true innovations. ${ }^{10}$ As the Supreme Court stated in 1950, the granting of patents for obvious and known methods "withdraws what is already known into the field of its monopoly and diminishes the resources available to skillful men." 11

There are several ways in which substandard patents can impose economic and welfare costs on the economy. As we describe in Part II below, a "loose" patent system - that is, a patent system that permits large numbers of substandard patents - causes deadweight economic losses because the presence of substandard patents diminish the overall level of innovation and development of valid patents. A valid patent, like a substandard patent, confers a

${ }^{7}$ See Kenneth W. Dam, The Economic Underpinnings of Patent Law, $23 \mathrm{~J}$. LEGAL STUD. 247, 247-48 (1994).

${ }^{8}$ Kitch adds that patents also promote efficiency by deterring others from engaging in wastefully duplicative efforts of re-inventing the same technology. Edmund W. Kitch, The Nature and Function of the Patent System, 20 J.L. \& ECON. 265 (1977); see also Dam, supra note 7, at 266-67.

${ }^{9}$ There is some dispute regarding the value of disclosure. See, e.g., Yossi Spiegel \& Reiko Aoki, Public Disclosure of Patent Applications, $R \& D$, and Welfare (Berglas Sch. of Econ. Working Paper No. 30-98, 1998).

${ }^{10}$ See Nancy T. Gallini, The Economics of Patents: Lessons from Recent U.S. Patent Reform, 17 J. ECON. PERSP. 131 (2002); Bronwyn H. Hall \& Rosemarie Ham Ziedonis, The Patent Paradox Revisited: An Empirical Study of Patenting in the U.S. Semiconductor Industry, 1979-95, 32 RAND 101 (2001) (patenting may be socially wasteful and accumulation of patents may redirect resources away from productive research).

${ }^{11}$ Great Atl. \& Pac. Tea Co. v. Supermarket Equip. Corp., 340 U.S. 147, 152-53 (1950). 
monopoly right to the holder, but a valid patent does so only in the case of genuine innovation. Valid patents then have a positive social value in addition to a private value, while substandard patents have only the private value. The deadweight losses occasioned by substandard patents will cause resources to be allocated inefficiently and therefore affect the entire economy. In addition, a "loose" patent system that grants large numbers of substandard patents also causes other inefficiencies and misallocations of resources, as such a system would:

- Cause consumers to absorb monopoly prices over "inventions" that were already effectively common knowledge; ${ }^{12}$

- Direct resources away from productive research and instead towards strategic accumulation of patents already filed over innovations already deployed; ${ }^{13}$

- Divert resources to "defensive patenting" or securing offensive "blocking patents;",14

- Direct research away from areas of existing patents that should not have been granted; ${ }^{15}$

- Direct resources toward acquiring and enforcing substandard patents and collecting royalties rather than productive fields of economic activity.

Given this potential for misallocating resources and the other costs, a well-functioning patent law regime should tailor the scope of the legal patent monopolies so that the harms described above are outweighed by the benefit to society from the economic innovation which results from those patent monopolies. As stated by Lévêque and Ménière, the "simple criterion" of economic welfare "helps define the elements of an optimal patent."16

Whether the United States patent system is "too loose" today is the subject of substantial debate. The claimed shortcomings of the USPTO and the United States court system are numerous and appear to stem primarily from a poor legal

\footnotetext{
12 "This deadweight loss reduces the total surplus created by the innovation at least during the lifetime of the patent." FRANÇOIS LÉVÊQUE \& YANN MÉNIÈRE, THE ECONOMICS OF PATENTS AND COPYRIGHT 21 (2004).

13 Jaffe \& Lerner describe a number of such activities including the sealed crustless sandwich and the perpetual option pricing formula of Vergil Daughtery. JAFFE \& LERNER, supra note 3, at 32, 145-47.

${ }^{14}$ See Gallini, supra note 10 (describing strategic practice of "defensive patenting"); Robert Merges, Intellectual Property Rights and Bargaining Breakdown: The Case of Blocking Patents, 62 TENN. L. REV. 75 (1994) (describing the similar strategic use of "blocking patents").

${ }^{15}$ See Gallini, supra note 10.

${ }^{16}$ LÉVÊQUE \& MÉNIĖRE, supra note 12, at 43.
} 
framework and an understaffed and overworked agency. The debate often centers around the patenting of "inventions" such as a method for swinging on a swing, the sealed crustless sandwich, a financial technique developed four decades prior to patenting by academics unaffiliated with the patentee, and anti-gravity flying machines. ${ }^{17}$ As observed by Magliocca, the United States court system, in many ways, exacerbates the problem, brought to light by the explosion of "patent troll" litigation. Patent trolls engage in a very specific arbitrage opportunity and thrive in certain conditions in which patents are easy to obtain and keep, the costs of defending a patent suit are great, and the risk to a defendant of losing a patent suit are enormous because the defendant "cannot easily substitute away from the disputed technology." thrive in situations in which patents are easy to get and damages uncertain. ${ }^{19}$ As Justice Kennedy observed in the $e$ Bay decision, a patent remedy such as a permanent injunction against an infringer "can be employed as a bargaining tool to charge exorbitant fees to companies that seek to buy licenses to practice the patent.",20

As a result, almost unique among industrialized nations, United States companies face a plethora of patent suits brought by plaintiffs with arguably substandard patents. ${ }^{21}$ There are some

${ }^{17}$ JAFFE \& LERNER, supra note 3, at 145-47; U.S. Patent No. 6,960,975 (filed Mar. 14, 2005) (granting patent for a "space vehicle propelled by the pressure of inflationary vacuum").

${ }^{18}$ Gerard N. Magliocca, Blackberries and Barnyards: Patent Trolls and the Perils of Innovation, 82 NOTRE DAME L. REV 1809, 1812 (2007).

${ }^{19}$ On the other hand, some commentators argue that "patent trolls" serve a useful purpose, most notably by providing liquidity to inventors as well as expertise in policing infringement. See, e.g., Steven Rubin, Hooray for the Patent Troll, IEEE SPECTRUM, Mar. 2007, http://spectrum.iee.org/consumerelectronics/gaming/hooray-for-the-patent-troll (“[P]atent-holding companies provide another way, and sometimes the only way, for an inventor to monetize his patent. They foster innovation by making it possible for small companies and individual inventors to spend their time in research and development, knowing that if a patent does issue, they will not necessarily have to commercialize or litigate it. They can spend time doing what they are good at-inventing."). But see Zachary Roth, Patent Troll Menace, WASH. MONTHLY, June 1, 2005, http://www.washingtonmonthly.com/features/2005/0506.rothsidebar2.html

("The reason this business is attractive to people such as Lockwood is simple: Trolling makes money. ... [E]ven though his patent was overturned, Lockwood still got to keep the licensing fees he had extracted from other targets that chose not to fight.").

${ }^{20}$ eBay, Inc. v. MercExchange, 547 U.S. 388, 396 (2006) (Kennedy, J., concurring).

${ }^{21}$ Patent trolls are largely a U.S. phenomenon. See, e.g., Joe Brennan et al., Patent Trolls in the U.S., Japan, Taiwan and Europe, 13 CASRIP NEWSLETTER, Spring/Summer 2006, http://www.law.washington.edu/Casrip/Newsletter/ default.aspx?year $=2006 \&$ article $=$ newsv13i2BrennanEtAl. We do not claim that most litigation by patent trolls is brought through substandard patents, only that trolls do bring such cases. That is why the pejorative "troll" is used. 
signs that reform is brewing. Several recent Supreme Court decisions have addressed the standards for granting and challenging a patent ${ }^{22}$ and trimmed back lower court rulings that had increased the business risk and harm from losing a patent lawsuit. ${ }^{23}$ The Patent Reform Act of 2007, directed at improving patent quality and changing patent remedies, has been approved by the House and Senate Judiciary Committees. Analyzing and understanding the economic welfare costs of the current United States patent system is clearly of importance to policymakers as they consider these reform proposals.

The welfare costs of the current United States patent regime can be estimated empirically by comparing the valid patent output of our regime to the patent system in Europe. In contrast to the United States, the European patent system, while certainly not perfect, has a relatively "tighter" standard for granting patents and the process is administered and enforced differently as well. By this discussion we do not mean to imply that the European patent system is better than the United States system or that it should be adopted here, but only to assert that the two legal regimes are different in a way that allows us to perform an empirical analysis of the current United States patent regime.

To obtain a patent in the United States, the invention must be new, useful and non-obvious. ${ }^{24}$ In the United States, unlike some other countries, the process for granting a patent is usually confidential and solely between the applicant and the USPTO, and other parties are not permitted to intervene or oppose a patent application. ${ }^{25}$ Moreover, the USPTO cannot simply reject a patent

${ }^{22}$ In KSR International Co. v. Teleflex Inc., 550 U.S. 398 (2007), the Court tightened the Federal Circuit's test for patentability, in particular the "obvious" standard. In MedImmune, Inc. v. Genentech, Inc., 549 U.S. 118 (2007), the Court overturned a Federal Circuit ruling that limited the ability of patent licensees to subsequently challenge the validity of a patent.

${ }^{23}$ In Microsoft Corp. v. AT\&T Corp., 550 U.S. 437 (2007), the Court overturned a Federal Circuit ruling that held Microsoft liable for computers manufactured and programmed abroad with software that infringed a United States patent. In $e B a y$, the Court ruled that traditional equitable principles should apply in patent disputes with regard to the granting of injunctions against infringing products; prior to that decision, lower courts had followed a "general rule" of always issuing such an injunction without considering the public interest.

2435 U.S.C. $\S 101$ (2006) (new and useful); id. $\S 103$ (non-obvious). For a recent Supreme Court discussion of the obviousness test, see KSR, 550 U.S. 398.

${ }^{25}$ Patent applications in the United States are not necessarily made public until after a patent is issued. 35 U.S.C. $\$ 122(\mathrm{a})$. Applications are not made public until 18 months after filed. Id. $\S 122(\mathrm{~b})(1)(\mathrm{A})$. Within two months after publication, third parties may submit prior art related to patentability. Manual of Patent Examining Procedure 1134.01. Upon issuances of a patent, the protection has a term of twenty years from the date on which the application was filed, but only upon issuance of a patent does the information disclosed in the application becomes a matter of public record. 35 U.S.C. $\$ 154$ (a). Until 1995, the term of a 
application; it also bears the burden of making a prima facie case that explains the reasons for rejection. Third parties do not have the right to participate in the patent application process and patents can only be challenged after a grant in limited instances, consisting of challenges based on prior art found in patents or printed publications. ${ }^{26}$ Moreover, in some instances, challenging a patent creates potential for the challenger to be estopped from asserting certain defenses in an infringement suit. ${ }^{27}$ Finally, in a suit for patent infringement, a plaintiff may obtain injunctive relief and damages, which may include lost profits due to the infringement or a reasonable royalty. ${ }^{28}$

Pursuant to the European Patent Convention, which harmonizes the patent laws of its signatories, twenty-year patents are available for "any inventions ... provided that they are new and which involve an inventive step and are susceptible of industrial application." 29 The standard for patentability in Europe, while similar to the United States in some respects, ${ }^{30}$ is different in other respects, particularly with regard to the European requirement that an invention be of a "technical" nature. ${ }^{31}$ In addition, patent applications in Europe are made public even if they have not been issued and the method for challenging a patent differs. As a result, a patent application in Europe is three times more likely to be opposed than a patent is to be reexamined in the United States. ${ }^{32}$ Of all the potential remedies to the United States patent system, remedying post-grant review process to adopt an

patent was seventeen years from the date of issuance. 35 U.S.C. $\S$ 154(a) (1988) (amended 1994).

${ }^{26} 35$ U.S.C. $\$ \S 301,302,311$ (2006).

${ }^{27}$ Id. $\$ 315(\mathrm{c})$.

${ }^{28}$ D.S. ChISUM, CHISUM ON PATENTS ๆๆ 20.01, 20.03 (1997).

${ }^{29}$ European Patent Convention art. 52(1), Nov. 29, 2000, available at http://www.epo.org/patents/law/legal-texts/html/epc/2000/e/contents.html.

30 Robert Stevenson, Software Patent Law: United States and Europe Compared, 2003 DUKE L. \& TECH. REV. 0006 (comparing U.S. "novelty" step to European "new" step).

31 European Patent Convention, supra note 29, §§ 29(1), 52(2). This "technical nature" requirement has led to different approaches in the United States and Europe over the patentability of software and "business method" patents. The European standard does permit the patenting of software directed at a technical process or that contains non-technical features. See, e.g., In re Sohei, 1995 O.J.E.P.O. 525 (Tech. Bd. App. 1994), available at http://legal.european-patentoffice.org/dg3/biblio/t920769ep1.htm.

${ }^{32}$ LÉVÊQUE \& MÉNIÈRE, supra note 12; see also Dietmar Harhoff \& Stuart J.H. Graham et al., Patent Quality Control: A Comparison of US Patent Reexaminations and European Patent Oppositions (Nat'l Bureau of Econ. Res., Working Paper No. w8807, 2002), http://emlab.berkeley/ bhhall/GHHM\% 20Nov02.pdf. 
approach more consistent with the European Patent Office (EPO) is by far the most commonly mentioned. ${ }^{33}$

Remedies for patent infringement are also different between the United States and Europe, and these differences appear to encourage more litigation in the United States. In particular, European law tends to favor payment of license fees and damages instead of injunctions over the future sale of infringing products, which have been more common in the United States. For example, in the United States, patent holders do not have a duty to license and their licensing actions are limited only by antitrust law, ${ }^{34}$ but in the United Kingdom, France, and Germany, compulsory license statutes require patent holders to license their products. ${ }^{35}$ While the Supreme Court in 2006 took action to limit the scope of permanent injunctions in patent disputes, ${ }^{36}$ injunctive relief is still available to patent holders in the United States. ${ }^{37}$ Jury trials to enforce patent rights and establish damages are not guaranteed in Europe as they are in the United States. In the United States, patent litigators often get a second bite of the apple as well,

${ }^{33}$ See, e.g., Patent Reform Act of 2007, S. 1455, 110th Cong. § 6. There are a number of papers offering options to improve the current patent system, primarily to protect against opportunism using substandard patents. See, e.g., David Barker, Troll or No Troll? Policing Patent Usage with an Open PostGrant Review, 2005 DUKE L. \& TECH. REV. 0009 (proposing that all patents be reviewed openly "whenever patents are renewed or sold"); James Bessen \& Michael Meurer, Lessons for Patent Policy from Empirical Research on Patent Litigation, 9 LEWIS \& CLARK L. REV. 1, 1-27 (2005); J. Farrell \& Robert Merges, Incentives To Challenge and Defend Patents: Why Litigation Won't Reliably Fix Patent Office Errors and Why Administrative Patent Review Might Help, 19 BERKELEY TECH. L.J. 1, 1-28 (2004); Michael Meurer, Controlling Opportunistic and Anti-Competitive Intellectual Property Litigation, 44 B.C. L. REV. 509, 509-44 (2003); Stuart Graham \& Dietmar Harhoff, Can Post-Grant Reviews Improve Patent System Design? A Twin Study of US and European Patents (CEPR Discussion Paper No. 5680, 2006); Stuart Graham \& Dietmar Harhoff, Would the U.S. Benefit from Patent Post-grant Reviews? Evidence from a 'Twining' Study (June 2005), ftp://ftp.zew.de/pub/zewdocs/veranstaltungen/graham_harhoff_paper.pdf.

${ }^{34}$ See Walker Process Equip., Inc. v. Food Mach. \& Chem. Corp., 382 U.S. 172, 179 (1965) (Harlan, J., dissenting).

${ }^{35}$ Stevenson, supra note 30, at 10.

${ }^{36}$ In the $e$ Bay decision, the Court reversed the court of appeals' "general rule" unique to patent disputes "that a permanent injunction will issue once infringement and validity have been adjudged." eBay, Inc. v. MercExchange, 547 U.S. 388, 393-94 (2006). According to Chief Justice Roberts, "[f]rom at least the early 19th century, courts have granted injunctive relief upon a finding of infringement in the vast majority of patent cases." Id. at 394 (Roberts, C.J., concurring).

${ }^{37}$ TiVo Inc. v. Echostar Comm. Corp., 446 F. Supp. $2 d 664$ (E.D. Tex. 2006) (granting injunction against Echostar after the eBay decision), rev'd in part, 516 F.3d 1290 (2008). 
because the United States Court of Appeals for the Federal Circuit reviews all patent claim determinations under a de novo standard. ${ }^{38}$

Patent suits in the United States are also generally more expensive than in Europe. Estimates indicate that the costs of a patent lawsuit through discovery are about $\$ 2$ million for each side. ${ }^{39}$ These costs are substantially higher than that in several European countries. In Germany, for example, the cost of a suit ranges from approximately $\$ 30,000$ to $\$ 80,000$. $^{40}$

We outline these differences between the European and United States patent regimes not to imply that the European regime is somehow preferable to the United States system, but simply to demonstrate how the United States system maintains a relatively "looser" patent system than Europe, thereby permitting more substandard patents. (The looseness of the patent system is logically separate from the costs of litigating patent claims, yet the high costs evident in the United States may strengthen the hand of patent trolls in pretrial negotiations.) That distinction is important as it serves as the basis for our estimation of deadweight losses and other costs described in Part III below. As described below, a "loose" patent system discourages the development and filing of valid patents and creates a deadweight loss for the economy. We base this estimate on the fact that even with a tighter legal standard for patentability, Europe produces a higher share of "valid" patents, relative to substandard patents, than the United States. Therefore, while the European system has been criticized as being too "tight," its relatively more stringent granting practices allow it to serve as a basis for our estimation approach.

\section{The Equilibrium LeVel of VAlid AND Substandard Patents}

The basis of our argument is that substandard patents arising from a "loose" patent system reduce the number of valid patents by discouraging innovation. While this idea is generally accepted, we formalize it here by describing the "correct" level of patenting in the sense of the equilibrium values of valid and substandard patents. To begin, we divide total patents into two

\footnotetext{
${ }^{38}$ Cybor Corp. v. FAS Tech., Inc., 138 F.3d 1448, 1456 (Fed. Cir. 1998) (en banc). District Court Judge James F. Holderman stated that because of this de novo standard of review in patent cases, "we United States District Court Judges feel like the late comedian Rodney Dangerfield, because our opinions 'get no respect." James F. Holderman, The Patent Litigation Predicament in the United States, 2007 U. ILL. J.L. TECH. \& POL'Y 1, 6.

${ }^{39}$ See, e.g., John Allison et al., Valuable Patents, 92 GEO. L.J. 435, 441 (2003) (estimating this figure for patents worth $\$ 1$ to $\$ 25$ million).

${ }^{40}$ Ray Black, Never Mind the Quality, Feel the Pinch, 2005 MANAGING INTELL. PROP. 26.
} 
types: (1) valid patents (v) and (2) substandard patents (b). Total patents are just $v+b$. Valid patents represent patents that are true inventions or discoveries in which the cost to society of granting a twenty-year monopoly to the patent holder are outweighed by the aggregate social benefit of the invention or discovery itself. Substandard patents are those which are granted that are of low quality (that is, for ideas that are not in fact new or non-obvious) and which create risks for valid patents through litigation and licensing. From the standpoint of our model, it is not necessary to assume that each and every patent of this sort is literally bogus, is created for a nefarious purpose, or is of no independent private value to the patentee. Our analysis simply assumes that such patents fall below an operative or ideal standard for approval and that they impose, on average, a harm to the economy as a whole and, specifically, a harm to so-called valid patents. More directly, the addition of a substandard patent reduces the private marginal benefit of a valid patent, and discourages the production of both valid and substandard patents (or inventions in general, whether patented or not).

The relationships between the flows of valid and substandard patents, and the assumed forms of the marginal benefits of these activities among agents in the economy, lie at the heart of our analysis, and therefore merit a brief discussion. First, valid patents, although they are differentiated by definition, are assumed here to be, broadly speaking, "competing" with one another. In other words, a valid invention will, on average, make money for its owner, but the product or service supported by the invention in question competes for the consumers' attention with all other products offered in the market. In a market populated by many innovative products, any individual product is, on average, less likely to make a high return. Thus we assume, as is common in economic analysis, that the marginal benefit of an additional valid patent decreases as more valid patents are awarded. This feature of the return to innovative activity is also consistent with the observation that high value projects are pursued "first", i.e., in almost all cases, while lower valued projects are funded only under more favorable conditions. The same logic applies to the diminishing marginal values of substandard patents.

The notion that increased numbers of valid patents will increase the marginal value of a substandard patent arises from the conceptualization of a substandard patent. Such a patent has value primarily (or solely) from its potential to support a patent claim against a valid, profitable patent. The more valid patents there are, the greater the probability such a claim can be constructed given an arbitrary substandard patent. Thus, the holder of a substandard patent would welcome increased numbers of valid patents, as this 
would raise her opportunity for privately profitable litigation. In a similar way, an increase in the number of substandard patents will adversely affect the expected profitability of a valid patent, since the risk of costly patent claims will increase.

To describe the equilibrium, we assume that patents (or patentable inventions) are ordered from highest to lowest, with resources devoted first to those patents with the greatest value. With diminishing marginal benefits to patents, the equilibrium number of valid patents, $v^{*}$, will solve:

$$
A(x)-a \cdot v-c \cdot b=0
$$

where the expression is the net private marginal benefit of an additional valid patent. ${ }^{41}$ The total benefit of valid patents is maximized where the marginal benefit of a valid patent is zero. The net marginal benefit includes a value $A(x)$, which is a function of exogenous factors $x$ such as the legal system for granting or challenging patents and the cost of enforcing patents. The parameter $a$ measures the reduction in the net marginal benefit of valid patents given the addition of one more valid patent, and the negative sign indicates diminishing marginal benefits. ${ }^{42}$ The relationship between the number and creation of substandard patents and the marginal value of a valid patent is measured by the parameter $c$. Substandard patents, on the other hand, reduce the net marginal benefit of valid patents. This consequence arises primarily from opportunistic litigation or licensing. Although they both represent a reduction in the value of a valid patent, both $a$ and $c$ are expressed as positive values.

The equilibrium number of substandard patents, $b^{*}$, will solve:

$$
B(y)-d \cdot b+e \cdot v=0
$$

where $B(y)$ is a scale factor for the net private marginal benefit of substandard patents, and its value is driven by a set of factors $y$. The factors $y$ will generally not be the same as $x$, but some overlap is to be expected. Intuitively, $y$ will encompass factors that measure the strength of the jurisdictional patent review process, the efficiency of the legal system, the generosity of patent

${ }^{41}$ In both Equation (1) and Equation (2), we have linear marginal benefits, but this assumption is not required and is for convenience only.

42 This reduction in marginal benefit presumably occurs because patent opportunities are exploited in order of decreasing expected net value, although the formulation is not inconsistent with the existence of an additional effect that reflects an actual reduction in the economic value due to competition between products which is increased or facilitated by new inventions. 
infringement awards, legal costs, and so on. The parameter $d$ is the effect on net private marginal benefits from the addition of one more substandard patent. And while $d$ is positive, the negative sign implies diminishing net marginal benefits. In contrast to Equation (1), an increase in the number of valid patents increases the net private marginal benefit of a substandard patent (because this increase creates more opportunities for litigation). The equilibrium number of both types of patents is determined by the condition that the marginal benefits of each are simultaneously equal to zero in the relevant jurisdiction.

Figure 1 is a graphical representation of the equilibrium. The figure has the number of substandard patents $(b)$ on the vertical and valid patents $(v)$ on the horizontal axis. The curves in the figures represent the loci of points where the marginal benefits of valid and substandard patents equal zero across the range of values of both $b$ and $v$ (i.e., iso-marginal benefit curves). The intersection of the two defines the equilibrium. In the figure, the equilibrium has $b^{*}$ and $v^{*}$ patents.

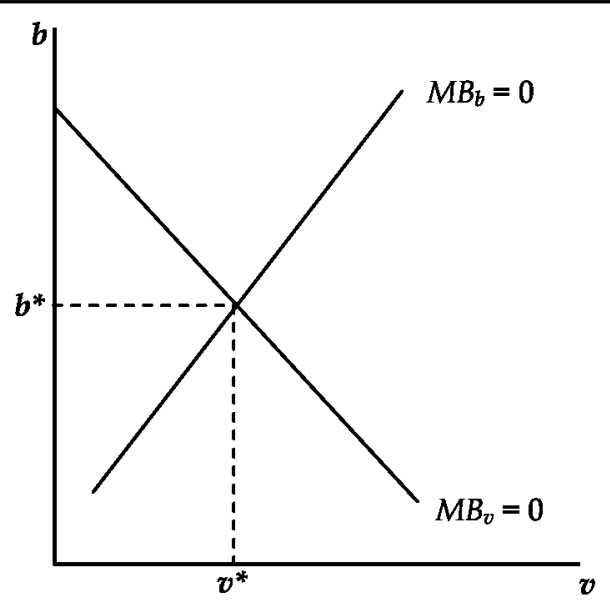

Figure 1. Patent Equilibrium

To demonstrate the comparative statics of the model, consider a court decision that makes the granting of substandard patents more difficult, such as the recent Supreme Court decision in $K S R$ that overturned lower court's permissive interpretation of the "non-obvious" test for patentability. In the model, this legal change is represented by a change in $y$ that reduces $B(y)$. Consequently, the number of substandard patents should diminish. In Figure 2, we illustrate this as a change in $y$ to $y^{\prime}$, causing a shift in the upward sloping iso-marginal benefit curve for substandard patents down and to the right. The new equilibrium is $b^{* *}$ and $v^{* *}$, 
where substandard patents fall and valid patents rise. Given our observation above that substandard patents diminish the value of valid patents and, therefore, reduce the incentive for firms to obtain such valid patents, upon the legal change that decreases the number of substandard patents, the number of valid patents will be expected to rise.

The comparative statics of the other parameters are similarly intuitive. Put simply, anything that increases the value of valid patents increases both $b$ and $v$. Any change that increases the value of substandard patents reduces $v$ and increases $b$. For example, a change in $x$ that makes valid patents more difficult to enforce will shift the iso-marginal benefit curve $\left(M B_{v}=0\right)$ down and to the left, thereby reducing both equilibrium valid and substandard patents.

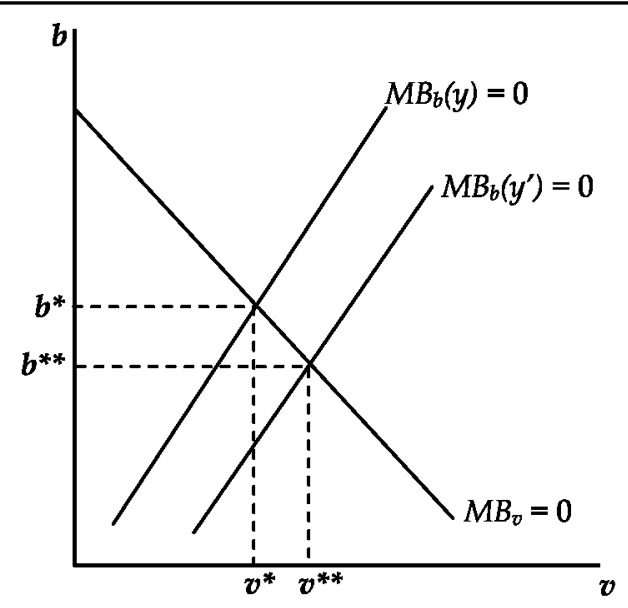

Figure 2. Patent Equilibrium

The most important point about this analysis is that it illustrates an aspect of the problem of the United States patent system that has received insufficient attention. In particular, since the numbers of both types of patents affect the marginal values of each, any policy change that affects either relationship will, in equilibrium, affect the numbers of both types. Of special potential concern is the size of the effect of substandard patents on the values of valid patents. To the degree that valid patents, as described here, have much larger net social values, a patent system that allows too many substandard patents is likely to reduce the extent of innovation valid patents support, reducing economic welfare. This dampening effect may be far more important than the direct costs of litigation and licensing, much of which will necessarily involve transfers. While direct legal costs are surely not 
de minimis, the discouragement of innovation, in the long run, will almost certainly swamp these more easily counted "direct" costs.

We also note that the underpinnings to our approach are conceptual. For example, we note that there is no need to assume that the socially optimal number of substandard patents need be zero, especially because there are costs associated with reducing substandard patents. For instance, adopting a patent regime that sets the bar high for granting any patent would certainly reduce or even eliminate the level of substandard patents, but that decision also could reduce the number of valid patents as well and therefore impose welfare losses on the economy. The administrative costs (and risk of mistakes) of sorting through valid and substandard patents may also be extraordinarily high. Like most things in economics and public policy, such a complete foreclosure of substandard patents would probably be too costly to be optimal in the real world. As a result, the efficient balance should be sought, and that appropriate balance is what a good patent policy must continually strive to achieve.

In addition, we are not assuming, and do not suggest, that substandard patents are intentionally created to use in opportunistic, socially destructive litigation or royalty seeking. It seems probable that very few patents are created with that primary end in mind. Rather, when the patent system is sufficiently "loose" in granting patents, and patents are had cheaply enough, firms and others will patent devices and procedures that are of limited commercial potential. In such cases, the possibility of obtaining an infringement award, or of licensing to others seeking legal defense, becomes a non-negligible consideration that encourages the patentee to proceed. Such expectations, of course, need to be accurate in equilibrium, so it must be the case that some opportunistic exploitation occurs. Since a patent is often an alternative to other means of protecting intellectual property, such as trade secret activity, one would expect that an increase in the number of potentially threatening patents would reduce the marginal benefit of a "valid" patent effort.

\section{Quantifying the Costs of Substandard Patents}

As discussed above, the presence of substandard patents leads to a reduction in the number of valid patents. In this Part, we attempt to quantify the loss of valid patents in the United States due to substandard patents, and then put a monetary value on that loss. As a first step, we estimate the number of valid patents lost to substandard patents. To do so, we assume, as have others, that triadic patents-i.e., those in which the inventor seeks patent protection in the United States, Europe, and Japan - are "relatively 
important" patents and are, to a large extent, generally regarded as "valid" patents. ${ }^{43}$ The validity of such patents is based on the fact that the patent must be granted by three patent offices: the USPTO, the EPO, and the Japanese Patent Office (JPO). By most accounts, the EPO is the most stringent in its requirements and evaluations, and we use that presumption below to specify some parameters of our estimation approach. We do not intend, however, to imply that the European patent system is the "correct" system. Rather, we assume, given the differences in the legal regime, that patents issued by the EPO are less likely to be substandard patents. This assumption, however, does not imply that the EPO system is in some sense ideal or perfect.

It is of course arguable that U.S. patents are, in some sense, qualitatively different from those in the European Union or Japan. This could be the case, for example, if the U.S. market were more important because of its size or profitability. Then, one might imagine valid inventions being patented only in the U.S. However, we find this conjecture unconvincing for several reasons. First, it seems unlikely one would have a patent for an invention that was profitable in the United States, but not in the European Union, for example. It is easier to imagine a profitable invention patented only in Japan, where cultural practices and relative prices are quite different (for example, it seems likely that a golf driving range device meant to be used atop tall buildings would be of more value in Japan). One might refer to this possibility as the "enculturation" of inventive activity.

More importantly, however, it seems undeniable that triadic patents are highly likely to be important, valid patents, even if there are valid patents that are not registered in all three jurisdictions. In this case, variations in the rates of triadic patents between jurisdictions will still provide a relative measure of lesser quality patents, although perhaps not universally substandard ones. Then, looking at the high rate of patents granted in the United States relatively to U.S. investment in R\&D, one is forced to conclude either that: (1) the United States is highly efficient in R\&D given its investments, or (2) the U.S. system generates a large number of dubious patents relative to the other jurisdictions. We base our calculations on the second of these interpretations.

Substandard patents are harmful in (at least) three respects. ${ }^{44}$ First, substandard patents may reduce future innovation

${ }^{43}$ JAFFE \& LERNER, supra note 3, at 143.

${ }^{44}$ See, e.g., U.S. FED. TRADE COMM'N, To Promote InNOVATION: THE Proper BALANCE OF COMPETITION AND PATENT LAW AND POLICY 146-151, available at http://www.ftc.gov/opp/global/report/gc_v1.pdf (2003); Richard Levin et al., Appropriating the Returns from Industrial $R \& D, 1987$ BROOKINGS PAPERS ON ECON. ACTIVITY 783, 831. 
by discouraging research and development in a particular area for fear of infringing, or directing research away from valid to substandard opportunities. ${ }^{45}$ This reluctance to enter could affect market structure and prices. Second, substandard patents may induce unnecessary licensing royalties, distorting the incentives the patent system was designed to provide. Third, legal challenges to substandard patents can result in socially wasteful litigation costs. Our focus here is on the first harm, and we attempt to estimate the welfare losses from high numbers of substandard patents. We believe these costs will be the largest of the three, and our rough estimates of the other costs indicate that this is true.

\section{A. Lost Patents}

The presence of substandard patents clearly reduces the incentives for firms to innovate. ${ }^{46}$ Yet, there is no direct evidence of which we are aware on the precise extent of research deterrence. In an effort to approximate the number of lost "valid" or "relatively important" patents lost due to the presence of substandard patents, we assume the production of relatively important patents is a linear function of R\&D expenditures. ${ }^{47}$ Thus,

${ }^{45}$ See, e.g., Nancy Gallini \& Suzanne Scotchmer, Intellectual Property: When Is It the Best Incentive System?, 2 INNOVATION POL'Y \& ECON. 51 (2002); Robert Merges \& Richard Nelson, On the Complex Economics of Patent Scope, 90 COLUM. L. REV. 839 (1990); Suzanne Scotchmer, Standing on the Shoulders of Giants: Cumulative Research and the Patent Law, 5 J. ECON. PERSP. 29 (1991).

${ }^{46}$ Jean Lanjouw \& Josh Lerner, Tilting the Table? The Use of Preliminary Injunctions, 44 J.L. \& ECON. 573 (2001); Josh Lerner, Patenting in the Shadow of Competitors, 38 J.L. \& ECON. 463 (1995). Hunt claims that the weakening of the non-obviousness requirement by domestic courts lead to more but weaker patents, and discouraged R\&D activity. Robert Hunt, Nonobviousness and the Incentive To Innovate: An Economic Analysis of Intellectual Property Reform (Fed. Reserve Bank of Phila. Working Paper No. 99-3, 1999); see also T.S. Ellis, Judge, Distortion of Patent Economics by Litigation Costs, Address at the 1999 CASRIP Summit Conference, in 5 CASRIP PUBLICATION SERIES: STREAMLINING INT'L INTELL. PROP. 22 (1999), available at http://www.law. washington.edu/casrip/Symposium/Number5/pub5atc13.pdf. ("My thesis today is neither revolutionary nor abstruse. On the contrary, it is no more than a modest, straightforward, common-sensical observation that has likely already occurred to many veteran viewers of the patent scene. It is, simply put, that the escalating, indeed skyrocketing litigation costs of the 1970's and 1980's have distorted patent markets and patent economics. Put another way, it is my observation that the escalating costs associated with litigating patent infringement and validity issues discourage challenges to patents, thereby essentially equating the entry barriers for presumptively valid, but weaker patents with those entry barriers associated with strong or judicially tested patents.").

${ }^{47}$ We are also evaluating log transformations of the variables using comparable $\mathrm{R}^{2}$ values, but the linear specification is superior to these alternatives. 
the number of triadic patents filed by country $i$ in period $t$ is described by

$$
F_{i, t}=\beta \cdot R N D_{i, t}+\theta \cdot D U S+\sum_{j=1}^{T} \alpha_{j} D_{j}+\varepsilon_{i, t}
$$

where $F_{i}$ is the number of triadic family patents for country $i$ in period $t, R N D$ is the real research and development expenditures for country $i$ in period $t, D U S$ is a dummy variable with a value of 1 for the United States ( 0 otherwise), the $D_{j}$ are $T(=\Sigma t)$ period specific dummy variables, the $\alpha_{i}$ are estimated coefficients, and $\varepsilon_{i, t}$ is the econometric disturbance term. ${ }^{48}$ The coefficient $\theta$ measures the extent to which the United States either under- or overproduces valid patents relative to other countries. Triadic patents are measured by the OECD using applications at the EPO and JPO and grants at the USPTO. ${ }^{49}$

All of the data required to estimate Equation (3) is from the Organisation for Economic Co-operation and Development's (OECD) Main Science and Technology Indicators. The variables are expressed in annual terms and cover the period 1995 through 2003. The variable $R N D$ is measured in two ways: civil R\&D and total R\&D (both civil and defense), and both are measured in real dollars (in millions). ${ }^{50}$ There is some evidence suggesting that defense spending on R\&D generates few patents, and the United States spends far more on defense R\&D than any other country in the sample. ${ }^{51}$ Thus, using only Civil R\&D (i.e., total R\&D less defense-related $R \& D$ ) provides a more conservative estimate of the number of lost valid patents. To demonstrate the conservative nature of using only Civil R\&D expenditures, we also present the results with the variable $R \& D$ measured using total $R \& D$ expenditures for comparison purposes. Given the large number of missing observations on the share of Civil R\&D spending, the

\footnotetext{
${ }^{48}$ Data required to estimate this equation is from the OECD's Main Science and Technology Indicators (Subscription Service). The variables are expressed in annual terms and cover the period 1995 through 2003, and with missing variables the sample size is 299 observations. The model is estimated using least squares with period dummy variables to account for the time series nature of the data. The coefficients are highly statistically significant and are $\beta_{0}=-396.6, \beta_{1}$ $=0.10$, and the year 2003 constant is -105.2 . Overall, the model performs well, with an $R^{2}$ of 0.80 . The linear specification fits the data quite well, much better than either the log-lin or log-log specifications.

${ }^{49}$ Application data at the USPTO was not available prior to 2003, leading to this definition of triadic patents by the OECD. ORG. FOR ECON. CO-OPERATION \& DEV. [OECD], Patent STATisTiCs ManUal 71 (2009).

${ }^{50}$ The GDP deflator is provided in the OECD data for those countries included in the sample.

${ }^{51}$ Aok Chakrabarti \& C. Leonard Anyanwu, Defense R\&D, Technology, and Economic Performance: A Longitudinal Analysis of the U.S. Experience, 40 IEEE TRANSACTIONS ON ENGINEERING MGMT. 136 (1993).
} 
share variable is assumed to be constant over the sample period (based on the average of available data). ${ }^{52} \mathrm{We}$ do not suspect this will bias the results significantly, since the available data suggests the civil share across all countries is very stable over time.

The OECD data provides data on thirty-eight countries, although there are some missing observations. We present the results of the estimation using three sets of countries. Sample A includes thirty countries with 227 total observations. ${ }^{53}$ This sample includes all countries for which the necessary data is available. For Sample B, we include only countries in the European Union and the United States, since the patent and legal regimes in these countries are more likely consistent with that of the United States. ${ }^{54}$ Finally, in Sample C, we include all thirty-eight countries available. ${ }^{55}$ In this sample, however, we are limited to total R\&D expenditures in nominal terms due to a lack of data. The results from this sample are provided for illustrative purposes only, and we do not discuss them in detail.

The model is estimated using least squares with period dummy variables to account for the time series nature of the data. ${ }^{56}$ Table 1 summarizes the results. Alternative procedures for computing the standard errors render no significant changes, so the t-statistics are based on the ordinary standard errors. All the variables are statistically significant. The model fits the data very well, with $\mathrm{R}^{2}$ values of about 0.97 across all specifications (except for Sample $\mathrm{C}$, with an $\mathrm{R}^{2}$ of 0.92 ). The good fit is not surprising given the time series component of the data.

Turning to the number of lost patents (measured by $\theta$ in Equation (3)), across Samples A and B we observe similar estimates when using Civil R\&D expenditures. The more conservative number, and probably the more sensible one given the comparison is across the United States and EU countries only, is

${ }^{52}$ For every year the data is available, we compute the ratio of Civil to Total R\&D (as a percentage of GDP), and then average these for each country.

${ }^{53}$ We have 30 countries and 9 years of data for a total of 270 potential observations, but there are missing values. The countries in Sample A include Argentina, Australia, Austria, Belgium, the Czech Republic, Denmark, Finland, France, Germany, Greece, Iceland, Ireland, Italy, Japan, Korea, Luxembourg, New Zealand, Norway, Portugal, Romania, the Russian Federation, Slovak Republic, Slovenia, South Africa, Spain, Sweden, Switzerland, Taiwan, United Kingdom, and United States.

${ }^{54}$ The countries in Sample B include Belgium, the Czech Republic, Denmark, Finland, France, Germany, Greece, Ireland, Italy, Luxembourg, Norway, Portugal, Slovak Republic, Spain, Sweden, Switzerland, Slovenia, United Kingdom, and United States.

${ }^{55}$ Thus, Sample C includes all countries listed supra note 53, plus Canada, China, Hungary, Israel, Mexico, the Netherlands, Poland, and Turkey.

${ }^{56}$ Using a time trend rather than dummy variables has almost no effect on the results. 
7266 triadic patents, with $90 \%$ confidence interval boundaries of 6205 and $8327[\operatorname{se}(\theta)=642.7]$. In the larger Sample A, lost patents rises to 8447 , with a $90 \%$ confidence interval bound by 7715 to 9181.

For both samples, the estimate of lost triadic patents is larger when using total R\&D expenditures $(12,004$ and 9406, respectively). This difference and its direction were expected, given the higher percentage of defense related expenditures in the U.S. and the low patent productivity of such expenditures. To be conservative, we assume there are 7000 lost triadic patents due to the presence of substandard patents in the United States, a round number that is at the lower end of our approximation technique (i.e., $\theta=7266$ ). 


\begin{tabular}{|c|c|c|c|c|c|}
\hline \multicolumn{6}{|c|}{ Table 1. Estimation of Lost Patents, Regression Results } \\
\hline \multirow[b]{2}{*}{ Variable } & \multicolumn{2}{|c|}{ Sample A } & \multicolumn{2}{|c|}{ Sample B } & \multirow{2}{*}{$\begin{array}{l}\text { Sample C } \\
\text { Coefficient } \\
\text { (t-stat) }\end{array}$} \\
\hline & $\begin{array}{l}\text { Coefficient } \\
\text { (t-stat) }\end{array}$ & $\begin{array}{l}\text { Coefficient } \\
\text { (t-stat) }\end{array}$ & $\begin{array}{l}\text { Coefficient } \\
\text { (t-stat) }\end{array}$ & $\begin{array}{l}\text { Coefficient } \\
\text { (t-stat) }\end{array}$ & \\
\hline Constant & $\begin{array}{r}-404.35 \\
(-8.23)\end{array}$ & $\begin{array}{r}-417.79 \\
(-7.14)\end{array}$ & $\begin{array}{r}-249.60 \\
(-4.63)\end{array}$ & $\begin{array}{r}-211.30 \\
(-3.51)\end{array}$ & $\begin{array}{r}-332.20 \\
(-4.89)\end{array}$ \\
\hline $\begin{array}{l}R N D \\
\text { (Civil R\&D) }\end{array}$ & $\begin{array}{r}0.123 \\
(60.19)\end{array}$ & $\cdots$ & $\begin{array}{r}0.115 \\
(36.44)\end{array}$ & $\cdots$ & ... \\
\hline $\begin{array}{l}R N D \\
\text { (Total R\&D) }\end{array}$ & .. & $\begin{array}{r}0.117 \\
(50.19)\end{array}$ & $\cdots$ & $\begin{array}{r}0.105 \\
(32.00)\end{array}$ & ... \\
\hline $\begin{array}{l}R N D \\
\text { (Nominal Total) }\end{array}$ & $\cdots$ & $\cdots$ & $\cdots$ & $\cdots$ & $\begin{array}{r}0.103 \\
(35.50)\end{array}$ \\
\hline$D U S$ & $\begin{array}{r}-8447.96 \\
(-19.01)\end{array}$ & $\begin{array}{r}-12003.74 \\
(-20.18)\end{array}$ & $\begin{array}{r}-7266.10 \\
(-11.30)\end{array}$ & $\begin{array}{r}-9405.96 \\
(-11.82)\end{array}$ & $\begin{array}{r}-8445.48 \\
(-11.29)\end{array}$ \\
\hline \multicolumn{6}{|l|}{ Period Constants } \\
\hline 1995 & -73.18 & -65.06 & 18.02 & 30.49 & 154.68 \\
\hline 1996 & -24.38 & -13.81 & 50.41 & 63.51 & 151.71 \\
\hline 1997 & 50.93 & 53.62 & 63.11 & 67.97 & 135.30 \\
\hline 1998 & 4.39 & 5.69 & -5.49 & -1.89 & 67.73 \\
\hline 1999 & 101.16 & 102.23 & 24.40 & 19.89 & 82.75 \\
\hline 2000 & 51.45 & 45.43 & -1.93 & -10.63 & -10.12 \\
\hline 2001 & -9.92 & -16.89 & -55.26 & -64.45 & -109.85 \\
\hline 2002 & -67.83 & -71.36 & -50.51 & -52.54 & -213.70 \\
\hline 2003 & -37.68 & -43.37 & -43.92 & -52.56 & -234.70 \\
\hline $\mathrm{R}^{2}$ & 0.98 & 0.97 & 0.98 & 0.98 & 0.92 \\
\hline Cross Sections & 30 & 30 & 19 & 19 & 38 \\
\hline Observations & 227 & 227 & 148 & 148 & 299 \\
\hline
\end{tabular}

Of course, a patent can be valid without being triadic (but we are assuming triadic patents are valid), since not all valid patents are worth filing triadically. As an approximation to the number of valid to triadic patents, we assume that more rigorous standards of the EPO render only valid patents (we relax this assumption later in our estimation procedure). The (average) ratio of valid patents to triadic patents can be approximated by

$$
P_{i, t}=\lambda \cdot F_{i, t}+\sum_{j=1}^{T} \alpha_{j} D_{j}+\varepsilon_{i, t}
$$

where $P_{i, t}$ is the number of patent applications by country $i$ in period $t$. Equation (4) is estimated in the same way as Equation (3) with period dummies $D_{j}$. Sample B is used since it includes only EU countries (18 countries, 162 observations). The $\lambda$ coefficient is estimated to be $3.0(t$-stat $=120.3) .{ }^{57} \mathrm{So}$, the ratio of total valid patents to triadic patents in a jurisdiction is approximately 3.0. Triadics are measured in terms of grants by the USPTO rather than

${ }^{57}$ The $\mathrm{R}^{2}$ of the model is 0.99 . 
applications as in the case of the EPO and JPO. Given $\lambda=3$ and a loss of 7,000 triadic patents due to the presence of substandard patents in the United States, both estimated above, the total loss of valid patents in the United States per year is estimated to be 21,000 patent grants (about $10 \%$ of patents granted annually by the USPTO). ${ }^{58}$ Over the period 1999 through 2003, applications in the US exceeded grants by about two-fold, so there is approximately a loss of about 40,000 applications for valid patents. ${ }^{59}$

Assuming, for illustrative purposes, a $20 \%$ leakage in the EPO of substandard patents, reducing $\lambda$ to 2.4 , we have 16,800 lost valid patents in the United States annually due to the research deterrence effects of substandard patents. If the EPO is too stringent, say leading to the rejection of $20 \%$ of valid patents filed, then $\lambda$ is 3.6 and lost U.S. valid patents is approximated by 25,200 . We can also vary the assumed loss of triadic patents, perhaps according to the estimated confidence interval, for even more approximations of the total loss of valid patents in the United States. Given the imprecise nature of all of these calculations, we believe it is prudent to consider a range of options when estimating the welfare loss from substandard patents.

Having set forth a method for determining the number of lost patents, the next step requires an estimate of how much each patent is worth. There exists a substantial literature on the economic value of patents. ${ }^{60}$ For our purposes, the most useful estimate is by Cockburn and Griliches, who estimate the average economic value of a patent as US\$1 million (in current dollars) or $\$ 2.4$ million adjusting for both inflation and economic growth. ${ }^{61}$ Certainly, the distribution of value is highly skewed, but for our calculations the average is suitable. To be conservative, for the benchmark case we assume an average value per valid patent of $\$ 1$ million, and we will also consider a range of potential values.

The calculation of the deadweight welfare loss from substandard patents is

$$
D W L=\lambda \cdot P_{\text {LOST }} \cdot V_{V A L I D}
$$

\footnotetext{
${ }^{58}$ Estimated according to OECD's Main Science and Technology Indicators.

59 USPTO, U.S. Patent Statistics Chart: Calendar Years 1963-2008, http://www.uspto.gov/web/offices/ac/ido/oeip/taf/us_stat.htm.

${ }^{60}$ Iain Cockburn \& Zvi Griliches, Industry Effects and Appropriability Measures in the Stock Market's Valuation of R\&D and Patents, 78 AM. ECON. REV.: PAPER \& PROC. 419 (1988) (providing a per-patent estimate of value).

${ }^{61} I d$. We use the consumer price index to convert the year 1980 estimate of $\$ 500,000$ to current dollars (258 in 1980 to 604 in 2006), and for economic growth we include the growth in GDP over the same period. These data are available at U.S. Dep't of Commerce, Bureau of Economy Analysis, http://www.bea.gov (last visited May 30, 2010).
} 
where $P_{L O S T}$ is lost valid patents and $V_{V A L I D}$ is the average value of a valid patent. In our benchmark case, we have

$$
D W L=3 \cdot 7,000 \cdot 1,000,000=21,000,000,000
$$

so our "point" estimate of the deadweight loss from substandard patents is $\$ 21$ billion annually. Given annual R\&D expenditures in this US of about $\$ 300$ billion, these losses represent about $7 \%$ of total R\&D spending per year.

We do not wish to exaggerate the precision of our estimation approach. A rudimentary sensitivity analysis seems unnecessary given the simple form of the damage calculations (in Equation (5)). For example, if we assume any of the inputs to the calculation is understated by $10 \%$, then the estimated cost increases by $10 \%$.

We do think a simulation approach that estimates a distribution of plausible values may be useful. In this simulation, we take our "point" estimates of the three inputs to Equation (5) as mean values, and allow each to vary according to a specified distribution. From the econometric estimate of $P_{L O S T}$, we observed a coefficient of variation of about 0.10 (i.e., standard error of the coefficient divided by the mean). For our simulation, then, we assume that $P_{L O S T}$ is distributed normally with mean 7000 and standard deviation 700 . We also assume that $V_{\text {VALID }}$ is distributed normally also with a coefficient of variation of 0.10 (so the $95 \%$ confidence interval is 0.8 million to 1.2 million). For $\lambda$, we also assign a coefficient of variation of 0.1 , and this choice renders a $95 \%$ confidence interval bound by 2.4 and 3.6. Our simulation includes 10,000 draws of random numbers from these distributions, and these numbers are inserted into Equation (5) to compute the cost of substandard patents. The resulting distribution is illustrated in Figure 3. 


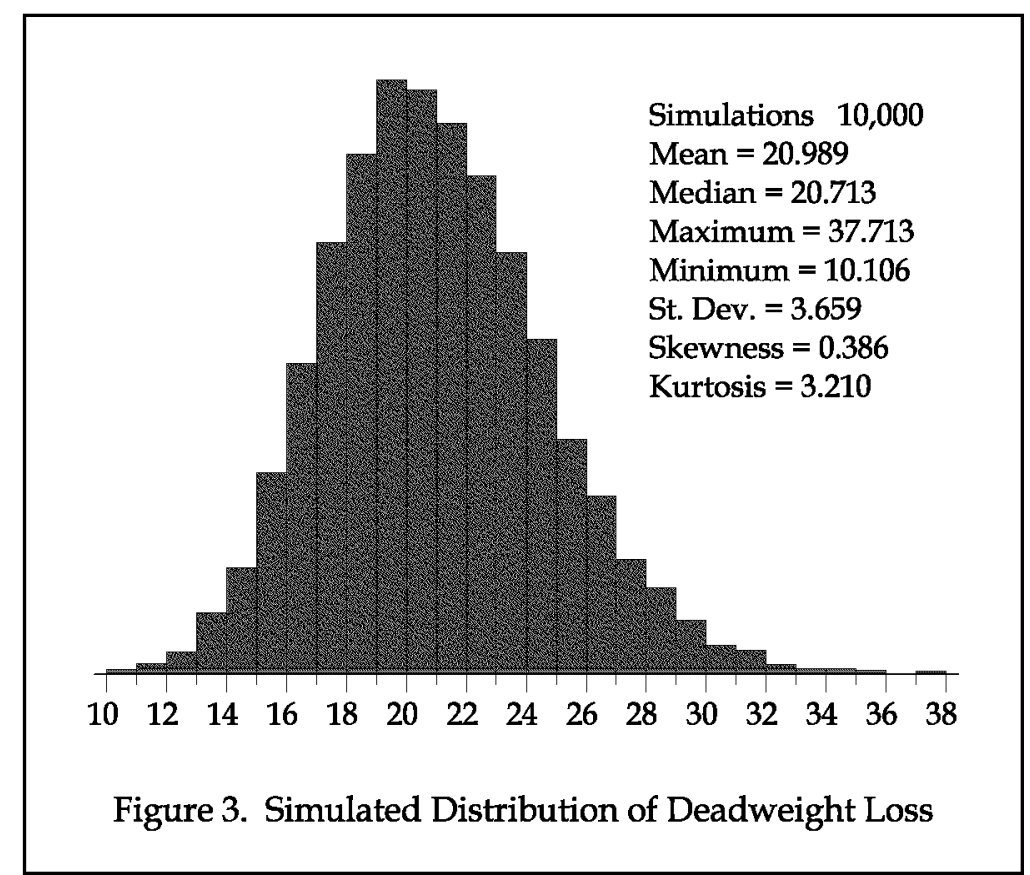

Figure 3 is the histogram of welfare costs of substandard patents from the simulation. The simulated mean of costs $(\$ 20.989$ billion) is essentially equal to the $\$ 21$ billion from Equation (6), as expected. The standard deviation is about $\$ 3.6$ billion (about $17 \%$ of the mean). The distribution has a slight positive skew, so it is not symmetrical. Repeating the simulation 100 times indicates the upper and lower bounds of the 95\% confidence interval are $\$ 14.4$ billion and $\$ 28.7$ billion. $^{62}$ For this particular simulation, the minimum value is about $\$ 10$ billion and the maximum about $\$ 38$ billion. ${ }^{63}$ We stress, however, that these calculations are illustrative since the nature of the random process is somewhat arbitrary. But, even with wide variation in the benchmark assumptions, the estimate of cost remains very high even at its smallest value ( $\$ 10$ billion annually).

\section{B. Other Deadweight Losses}

As mentioned above, we suspected that the research deterrence costs would be the largest of the deadweight losses from a loose patent system. There are, however, other costs. One direct cost of substandard patents relates to the typical administrative costs of pursuing substandard patents including legal fees, application fees, and the cost of the USPTO. These costs are

${ }^{62}$ This confidence interval is not symmetric around the mean $(-6.6$ billion and +7.7 billion).

${ }^{63}$ Given the very large number of simulations, the minimum, maximum, and confidence intervals are stable across runs. 
deadweight losses. In the United States, the legal and filing fees are estimated to be a few thousand dollars for even a simple patent to upwards of $\$ 25,000$ for more complex technologies. Offered estimates of costs from a variety of sources typically fall in the $\$ 3000$ to $\$ 25,000$ range per application. ${ }^{64}$ For our computations, we assume that the patent application costs $\$ 7500$, on average, in legal and administrative fees.

These costs must be applied to some estimate of the number of substandard patents filed each year. According to OECD data, over the five-year period 1999 through 2003, there were 90,445 triadic patents filed from the United States (recall that triadic patents are counted by grants for the USPTO). ${ }^{66}$ From above, we estimated the ratio of valid patents to triadic patents to be 3.0. ${ }^{67}$ Applying our $\lambda$ to the United States, we would expect that there would be approximately 271,335 valid patent grants in the United States over this period. However, there were 594,827 patents granted the USPTO in this period, which suggests that approximately half of all U.S. patents granted are substandard. ${ }^{68}$

While this percentage of substandard patents is high, it is consistent with other evidence. For example, Graham and Harhoff calculate that about $40 \%$ of U.S.-granted patents are rejected by the EPO, though the number is found to be much lower (about 4\%) in Jensen et al. ${ }^{69}$ Not all United States patents are also filed at the

${ }^{64}$ Gene Quinn, Cost of Obtaining a Patent, IPWatchdog.com, Dec. 31, 2007, http://www.ipwatchdog.com/patent/patent-cost. On average, the USPTO's average cost per patent reviewed is about $\$ 4000$. See also Techtransfer, Univ. of Mich., Patents and Other Legal Protection, http:/www.techtransfer.umich.edu/ resources/inventors/patents.php (last visited Apr. 9, 2010); What Does It Cost To Obtain a Patent, http://www.basicpatents.com/patcost.htm (last visited Apr. 9, 2010); You Want To Be an Inventor, http://www.inventored.org/novice (last visited Apr. 9, 2010); Cost of a Patent, http://www.costhelper.com/cost/small -business/patent.html (last visited Apr. 9, 2010). In some cases, patent prosecution costs must be incurred which could increase the cost by another $\$ 5000$ to $\$ 15,000$. U.S. DEP'T OF COMMERCE, FY 2006 PERFORMANCE \& ACCOUNTABILITY REPORT app. A, at 316 (2006), http://www.osec.doc.gov/bmi/ Budget/06APPR/PAR06.pdf.

${ }^{65}$ Over the period 2003 through 2005 , the USPTO earned about $\$ 3.3$ billion in revenue from 1.14 million applications, for an average application cost of about $\$ 3000$. U.S. PATENT \& TRADEMARK OFFICE, FY 2006 PERFORMANCE AND ACCOUNTABILITY REPORT, MANAGEMENT'S DISCUSSION AND ANALYSIS (2006).

${ }^{66}$ Estimated according to OECD's Main Science and Technology Indicators.

${ }^{67}$ For that same period, European countries (EU25) filed 79,295 triadic patents and 250,275 applications at the EPO. Thus, dividing the two, we compute a $\lambda$ of 3.16 , which is very close to our estimated $\lambda$ of 3.0 .

${ }^{68}$ Estimated according to OECD's Main Science and Technology Indicators.

${ }^{69}$ Paul H. Jensen et al., Disharmony in International Patent Office Decisions, 15 FED. CTR. BAR J. 679, 690 (2006); Stuart J.H. Graham \& Dietmar Harhoff, Separating Patent Wheat from Chaff: Would the U.S. Benefit from Adopting a Patent Post-Grant Review? (Oct. 14, 2009), http://ssrn.com/abstract=1489579. 
EPO (U.S. entities file about $15 \%$ as many applications annually at the EPO as they do the USPTO), but one would initially think that those filed at the EPO by American entities would be of relatively high quality. ${ }^{70}$ Allison and Lemley, in a study of patents litigated over the period 1989 through 1996, reveal that about half of litigated patents are invalidated at trial. ${ }^{71}$ Further, Trajtenberg argues that cited patents, and not simple patent counts, are correlated with patent value. In his data, about half of patents are not cited, again suggesting that about half of patents may be classified as substandard. ${ }^{72}$ Finally, Jaffe and Lerner summarize evidence from the OECD indicating that the growth rate of USPTO granted patents is twice that of "economically significant" (or triadic) patents. ${ }^{73}$

Assuming $50 \%$ of filings are substandard and there are 400,000 filings per year, there are about 200,000 substandard patent filing at the USPTO annually. ${ }^{74}$ At an average cost of $\$ 7500$ per application, the annual deadweight loss from administrative costs related to the acquisition of substandard patents is $\$ 1.5$ billion. While this is certainly a large number and a significant cost of substandard patents, it is far below the costs of research deterrence caused by substandard patents.

Substandard patents also lead to litigation. While judgments are properly viewed as transfers, the costs of obtaining judgments (or royalties) are deadweight losses. In order to determine the expected cost of litigation from substandard patents, we need an estimate of the probability a patent is litigated and the cost of litigation. As for litigation rates, Lanjouw and Shankerman find a domestic litigation rate of about $1.6 \%$ during the early

Grant rates are highly contested figures. See, e.g., Cecil Quillen \& Ogden Webster, Continuing Patent Applications and Performance of the U.S. Patent Office, 11 FED. CTR. BAR J. 1 (2001) ("The Grant Rate (allowances divided by total disposals, i.e., the sum of allowances and abandonments) for the USPTO for its fiscal years 1993-1998, corrected for continuing applications, ranges from $87 \%$ to $97 \%$, depending on the extent to which prosecution of abandoned applications was continued in re-filed applications. Reported Grant Rates for 1995-1999 for the European and Japanese Patent Offices (averaged) are 67\% and $64 \%$, respectively.").

${ }^{70}$ FOUR OFFICE STATISTICS REPORT fig. 4.2, at 41 (2008), http://www.trilateral. net/statistics/tsr/statisticsreport/fullreport.pdf.

${ }^{71}$ John Allison \& Mark Lemley, Empirical Evidence on the Validity of Litigated Patents, 26 AM. INTELL. PROP. L. ASS'N Q.J. 185, 205 (1998).

${ }^{72}$ Manuel Trajtenberg, A Penny for Your Quotes: Patent Citations and the Value of Innovations, 21 RAND J. ECON. 172, 181 (1990).

73 JAFFE \& LERNER, supra note 3, at 143.

${ }^{74}$ Our statistical analysis is based, by necessity, on grants for the USPTO. Annually, applications are roughly twice grants. 
1980s. ${ }^{75}$ Allison et al. report a $3.2 \%$ litigation rate. ${ }^{76}$ The litigation rate from these studies depend on a number of things including the stock of patents and time period evaluated.

For our purposes, we are constructing annual estimates of the cost of substandard patents. Federal statistics indicate that there are approximately 3000 patent cases filed annually. Allison et al. show that most litigated patents are younger, typically being three years or less. ${ }^{77}$ Thus, we construct a patent stock of relatively recent patents. Over the most recent five years for which there is data (2004-2008), the USPTO has granted nearly one million patents, so we assume the stock of patents is 1 million and construct an annual litigation rate using that stock. ${ }^{78}$ So, a reasonable proxy for the annual litigation rate is $0.3 \%$ (or 3 cases per 1000 patents) on the stock of patents (both valid and substandard).

The cost of litigation varies substantially across patents, but the average is typically claimed to be in the $\$ 1$ million to $\$ 4$ million range for the discovery phase (about half the cost of a full trial). ${ }^{79}$ Allison et al., citing the American Intellectual Property Law Association, state that a patent case can cost $\$ 1.5$ million per side. ${ }^{80}$ Only about $5 \%$ of cases actually go to trial, with $95 \%$ being settled at some point in the process. ${ }^{81}$ In a recent economic simulation of patent litigation, Graham and Harhoff use a cost of litigation of $\$ 5$ million based on estimates from the American Intellectual Property Law Association. ${ }^{82}$

In light of the evidence, as a benchmark we assume a litigation rate of $0.3 \%$ and a litigation cost of $\$ 2$ million per case. The stock of patents is assumed to be one million (which approximates patents granted in the past five years) and we assume that half the patent stock is substandard. ${ }^{83}$ Thus, the approximate

\footnotetext{
${ }^{75}$ Jean Lanjouw \& Mark Schankerman, Characteristics of Patent Litigation: A Window on Competition, 32 RAND J. ECON 129, 135 tbl.1 (2001) (counting 16.4 cases per 1000 patents).

${ }^{76}$ Allison et al., supra note 39 at 477 fig. 1.

${ }^{77} \mathrm{Id}$.

${ }^{78}$ U.S. Patent Statistics Chart: Calendar Years 1963-2008, http://www.uspto. gov/web/offices/ac/ido/oeip/taf/us_stat.htm (last visited May 30, 2010).

${ }^{79}$ AM. INTELL. PROP. LAW ASS'N, 2009 REPORT OF ECONOMIC SURVEY 29 (2009); COALITION FOR PATENT FAIRNESS, THE CASE FOR REFORM, http://www.patentfairness.org/pdf/whitepapers/Patents_by_the_numbers.pdf.

${ }^{80}$ Allison \& Lemley, supra note 71.

${ }^{81}$ Fabrizio Cesaroni \& Paula Guiri, Intellectual Property Rights and Market Dynamics (LEM Working Paper Series No. 10, 2005).

${ }^{82}$ Graham \& Harhoff, supra note 69.

${ }^{83}$ On average, a patent is five years old when litigated. Benjamin Hershkowitz, What Are My Chances? From Idea Through Litigation, FindLaw.com, http://library.findlaw.com/2003/Oct/16/133092.html (last visited May 30, 2010); see also Allison et al., supra note 39. Summing over a longer period would
} 
deadweight loss from the litigation of substandard patents is $\$ 3$ billion annually. ${ }^{84}$ While this is also a very large number, it again remains much smaller than the $\$ 21$ billion annual cost of research deterrence.

\section{Review of the Evidence}

Our analysis shows that the cost of a "loose" patent system that is prone to grant substandard patents is very high. Much of the cost is attributable to the reduced innovation, but the administrative and litigation costs are non-trivial. We estimate that annually, the deadweight loss from reduced innovation is $\$ 21$ billion, administrative costs $\$ 1.5$ billion, and litigation costs $\$ 3$ billion. The total of these deadweight losses that we calculate is $\$ 25.5$ billion annually. We stress that these estimates are preliminary. As such, we have provided a range of probable values to demonstrate the change in estimates given alternative assumptions. Certainly more research is needed on this very important topic.

\section{Conclusion}

The purpose of patent policy is to balance the incentive to invent with the ability of the economy to utilize and incorporate new inventions and innovations. Because patent law grants de jure monopolies to patent holders and provides those holders with substantial rights to prevent infringement or sue for substantial damages, it is crucial that such patents be awarded only for truly original innovations. As Justice Kennedy recently wrote,

We build and create by bringing to the tangible and palpable reality around us new works based on instinct, simple logic, ordinary inferences, extraordinary ideas, and sometimes even genius. These advances, once part of our shared knowledge, define a new threshold from which innovation starts once more. And as progress beginning from higher levels of achievement is expected in the normal course, the results of ordinary innovation are not the subject of exclusive rights under the patent laws. Were it otherwise patents might stifle, rather than promote, the progress of useful arts. ${ }^{85}$

increase the estimated litigation costs, so the estimates here might be considered conservative.

${ }^{84}$ The calculation is $0.50 * 1000000 * 0.003 * 2000000=\$ 3$ billion.

${ }^{85}$ KSR Int'1 Co. v. Teleflex Inc., 550 U.S. 398, 398 (2007). 